\title{
Reproductive Biology of Habranthus tubispathus
}

\author{
Ana Clara Fernández ${ }^{1}$, Pablo Marinangeli ${ }^{1,2}$, \\ Gabriela Facciuto \\ Néstor Curvetto ${ }^{1}$ \\ Instituto de Floricultura; INTA Castelar \\ ${ }^{1}$ CERZOS (CONICET-UNS). \\ Camino La Carrindanga Km 7. Bahía Blanca \\ Argentina \\ ${ }^{2}$ Dto. de Agronomía. Universidad Nacional del Sur. \\ San Andrés 800. Bahía Blanca. Argentina.
}

Keywords: herkogamy, pollination, seed set

\begin{abstract}
Habranthus tubispathus is a bulbous species native to the sub humid and semiarid Pampean regions of Argentina, with a high aesthetic ornamental value for sustainable landscaping. In order to initiate breeding programs, the reproductive biology of the species was investigated. Self- and cross-pollinations were done on plants collected from a natural population. Fruits set were recorded in both self- and cross-pollinated plants, as well as in open-pollinated plants from the natural population. The fructification ratio, the reproductive success (RS) and the compatibility index were obtained. Also, observations of pollen tube growth in pistils of both types of pollination were evaluated. Self- and cross-pollinated plants set fruits. The fruit setting was lower in self-pollinated plants $(59.4 \%)$ as compared to crosspollinated ones $(91 \%)$, which showed similar setting as open-pollinated plants $(93 \%)$. Accordingly, RS values were 0.26 and 0.37 for self-pollinated and cross-pollinated plants, respectively. The growth of the pollen tubes (more than 100 tubes reaching the ovary) and the quantity of seeds per fruit (53) did not differ among self and crosspollinated plants. Another evidence of $\mathrm{H}$. tubispathus outbreeding is the presence of herkogamy in flowers, despite that this species exhibits partially self-compatible with the compatibility index value of 0.65 .
\end{abstract}

\section{INTRODUCTION}

The Amaryllidaceae are either herbaceous or succulent perennial species, forming underground storage organs such as bulbs, rhizomes or corms with linear to lanceolate leaves, and conspicuous flowers (Cabrera, 1968). Many species are well-known for the alkaloids which have been found to exhibit interesting pharmacological and/or biological properties (Arrigoni et al., 1997; Viladomat et al., 1997; Bi et al., 1998; SchmedaHirschmann et al., 2000). The most studied bioactive effects are non-specific inhibitions, such as antiviral and antitumoral activities (Gabrielsen et al., 1992; Pettit et al., 1995; Weniger et al., 1995). However, the numerous recognized genera of this family have ornamental uses like Narcissus and Hippeastrum and genera with ornamental potential such as Habranthus (Hurrell et al., 2005).

Habranthus tubispathus is a perennial bulbous species native to the sub humid and semiarid Pampean regions of Argentina (Cabrera, 1968), reported to occur in the provinces of Buenos Aires, Entre Ríos, Corrientes, and Santa Fe (Zuloaga et al., 2008). Habranthus tubispathus has attractive sub-erect with zygomorphic flowers with pink, yellow to reddishbrown or nearly white six tepals with funnel shaped perianth. Fruits are capsular, 3- 
loculated, subglobose or oblate. Capsules have numerous dark brown to black, flat, Dshaped, obliquely winged seeds.

Usually found in dense colonies, flowering in summer synchronously few days after a rain, when no vegetative structures are visible above the soil. Leaves develop during the fall and winter. The profuse and synchronous summer flowering make it a valuable resource due to its ornamental potential in sustainable landscaping. The use of these native resources for development of ornamental plants is still at an initial stage (Cáseres et al., 2001; Frayssinet and Cáseres, 2002; Sills et al., 2002). Proper establishment needs the acquisition of both knowledge and suitable tools to allow the domestication and suitable managing of $H$. tubispathus.

Studies on breeding system, seed production, rate and type of pollination are essential for the comprehension of the gene flow mechanisms within and between populations (Barrett and Eckert, 1990). Establishment of a plant breeding strategy needs to compare self- vs. cross-pollination, a central issue in studies of reproductive biology. Controlled self-pollination analysis gives suitable information about fruit and seed set. Studies of out-crossing rate reflect seed production under natural conditions with the stigma exposed to foreign pollination as well as to geitonogamy -the pollination of a flower with the pollen from another flower on the same bulb- and self-pollination.

In order to initiate breeding studies in H. tubispathus, the reproductive biology was investigated considering the following aspects: (1) degree of self-compatibility, (2) reproductive efficiency, (3) growth of the pollen tubes in the ovaries, and (4) seed production from self-, cross-, and open-pollinated flowers.

\section{MATERIALS AND METHODS}

Plants of $H$. tubispathus were collected from a natural population at Bahía Blanca $\left(38^{\circ} 42^{\prime} \mathrm{S}, 62^{\circ} 16^{\prime} \mathrm{W}\right)$, at flowering in order to ensure the identity of the species. Then, plants were grown in pots in a soilless potting substrate (GrowMix, Terrafertil) under greenhouse conditions.

Flowers were emasculated before anthesis to perform cross-pollinations in 2009 and 2010. Cross-pollination proceeded with pollen from plants of the same population; then flowers were covered to avoid pollen contamination. In 2009, self-pollination was achieved covering the flowers before anthesis and shaking them gently during anthesis. In 2010, flower covers were removed during anthesis and self-pollination was forced by contacting the stigmas with dehiscent anthers. Also, additional flowers were emasculated before anthesis, covered without pollination, and observed for fruit and seed formation.

The number of fruits set was recorded in both self and cross-pollinated plants, as well as in open-pollinated plants from the natural population that grew naturally in field. These data was collected from individual plants identified in the field, during three consecutive flowering seasons from 2008 to 2011.

The percentage of fruit setting (Fruit setting $(\%)=$ number of fruit set/ number of pollinated flowers x 100) and the Pre-emergent Reproductive Success of Wiens et al. (1987): $(\mathrm{RS}=$ number of fruits/ number of pollinated flowers) $\mathrm{x}$ (average number of seeds for fruit/ average number of ovules/ ovary) were calculated. An Index of selfincompatibility (ISI) was also calculated by dividing the average number of fruit setting per flower self-pollinated by the same following hand cross-pollination (Zapata and Arroyo, 1978). 
Pollen tube growth was studied in fixed pistils following self- and cross-pollination. The pistils were collected 24 hours after pollination and fixed in formaldehyde:acetic acid:ethanol $(\mathrm{FAA}=1: 0.5: 8 \mathrm{v} / \mathrm{v})$, for at least 24 hours at room temperature. Then, they were rinsed in distilled water and treated with $8 \mathrm{~N} \mathrm{NaOH}$ at $60^{\circ} \mathrm{C}$ for two hours (Martin, 1959). To detect pollen tubes, callose present in the pollen tube wall was evidenced as follows: pistils were rinsed with tap water and stained with $1 \%$ solution of aniline blue for one hour. Stained pistils were finally mounted on a microscope slide using a drop of the staining solution, and gently pressed with a cover slip. Pollen tubes reaching the ovaries were recorded using an epifluorescence microscope of (OLYMPUS BX 50, Japan) with excitation and emission filters at 330-385 $\mathrm{nm}$ and $420 \mathrm{~nm}$, respectively.

\section{RESULTS AND DISCUSSION}

Fruits were obtained in both self-pollinated and cross-pollinated plants (Table 1). The degree of fruits production depended on the type of pollination. The fruit setting was lower in self-pollinated plants (59.4\%) compared with cross-pollinated ones (91\%), that showed a similar fruit setting than open-pollinated plants (93\%). Consistently, RS of 0.37 and 0.26 were obtained for the cross-pollinated and self-pollinated plants, respectively. Emasculated and not pollinated flowers produced no fruits at all.

On the other hand, the quantity of seeds obtained per fruit was similar in both cases (Table 1), with an average of 54.4 seeds for the self-pollinated plants and 51.1 seeds for cross-pollinated plants. In the Amaryllidaceae Narcissus triandrus (Sage et al., 1999) and Hippeastrum advenum (Saavedra et al., 1996) self-pollination produced a lower number of seeds than cross-pollination. Nevertheless, Broyles and Wyatt (1991) found that Zephyranthes atamasco, a species belonging to the same tribe that $H$. tubispathus, produced the same quantity of seeds in fruits from both types of pollination.

In our experiments, the ISI for $H$. tubispathus was 0.65 . The score for selfcompatible species is 1 , incompletely compatible species present values between 0 and 1 , while for self-incompatible species the upper limit is 0.2 (Bawa, 1974; Ruiz and Arroyo, 1978). Then, taking in account this scoring scale, H. tubispathus should be considered a partially auto-compatible species.

The observation of pollen tube growth (Fig. 1) revealed that in pistils of self- and cross-pollinated flowers, pollens germinated and reached the ovaries in large quantities (more than 100 pollen tubes reaching the ovaries), which was consistent with the number of seeds obtained (Table 1).

From the results of self-pollinations, it is possible to state that $H$. tubispathus is a self-compatible species, although the stigma is above the level of the anthers. Indeed, we found that 3 anthers were closer to the stigma and had an average distance of $1.1 \mathrm{~mm}$ below, and the other 3 were further apart and had an average distance of $5.3 \mathrm{~mm}$ below the stigma. This flower morphology is a case of herkogamy, term referring to the spatial separation of pollen presentation and pollen receipt (Webb and Lloyd, 1986; Endress, 1996). Particularly, for H. tubispathus, fruit setting reached $60 \%$ in forced self-pollinated plants, compared with 36\% in plants were self-pollination was achieved by covering and gently shaking the flowers. This difference could be due to the occurrence of herkogamy in this species, which, according to the flower morphology, could be an unordered herkogamy or an ordered approach herkogamy (Webb and Lloyd, 1986).

As Webb and Lloyd (1986) concluded, herkogamy is more likely to have evolved to prevent interference between the pollen-dispersing and pollen-receiving functions of 
flowers, than to enhance out-crossing. In support of this view, they observed that many species with herkogamous flowers are also self-incompatible. In the Amaryllidaceae, herkogamy occurs in several species with stigmas strongly exerted, forcing insect visitors to contact stigmas before to anthers surfaces (Brantjes and Bos, 1980; Webb and Lloyd, 1986; Endress, 1996). Like other long-styled species such as Z. atamasco (Broyles and Wyatt, 1991), H. tubispathus is at least partially self-compatible, and the quantity of seeds produced from self-pollination and cross-pollination is similar. However, fruit set is higher when self-pollination is forced by placing the pollen on the stigma, instead of just covering the flower. Then, the presence of herkogamy would be a mechanism that favors cross pollination in $H$. tubispathus, while self-pollination is still possible. Another possible mechanism that favor cross-pollination is dichogamy (protandry or protogyny), which is a temporal isolation of male and female organs maturity within a perfect flower (Lloyd and Webb, 1986). This mechanism does not seem to be present in H. tubispathus (data not shown).

\section{CONCLUSIONS}

Habranthus tubispathus is a incompletely self-compatible species and has a preference for out-crossing. These results have implications in the domestication and breeding system for the species.

\section{ACKNOWLEDGEMENTS}

We thank Consejo Nacional de Investigaciones Científicas y Técnicas, Agencia Nacional de Promoción Científica y Tecnológica and Universidad Nacional del Sur for financial support (PICT 1375).

\section{Literature Cited}

Arrigoni, O., De Gara, L., Paciolla, C., Evidente, A., De Pinto, M.C. and Liso, R. 1997. Lycorine: A powerful inhibitor of L-galactono- $\gamma$-lactone dehydrogenase activity. J. of Plant Physiol.150:362-364.

Bawa, K. S. 1974. Breeding systems of tree species of a lowland tropical community. Evol. 28:85-92.

Bi, Y.R., Yung, K.H. and Wong, Y.S. 1998. Physiological effects of narciclasine from the mucilage of Narcissus tazetta L. bulbs. Plant Sci. 135:103-108.

Brantjes, N.B. and Bos, J.J. 1980. Hawkmoth behaviour and flower adaptation reducing self-pollination in two Liliflorae. New Phytol.84:139-143.

Barrett, S.C.H. and Eckert, C.G. 1990. Variation and evolution of mating systems in seed plants. In: S. Kawano (ed.), Biological approaches and evolutionary tends in plants. Academic Press. London. pp. 229-254.

Broyles, S.B. and Wyatt, R. 1991. The breeding system of Zephyranthes atamasco (Amaryllidaceae). Bull. of the Torrey Bot. Club 118:137-140.

Cabrera, A. 1968. Flora de la Provincia de Buenos Aires. Colección Científica del INTA. Buenos Aires, Tomo 4, Parte 1a. Ediciones INTA. Buenos Aires. 623 p.

Cáseres, G., Sills, C., Basso A. and Frayssinet, N. 2001. Habranthus brachyandrus y $H$. martinezii: análisis cariotípico de muestras poblacionales nativas y de la progenie de cruzamientos interespecíficos. Bol. Soc. Arg. Bot 103. 
Endress, P.K. 1996. Diversity and evolutionary biology of tropical flowers. Cambridge tropical biology series. Cambridge University Press. Cambridge. $511 \mathrm{p}$.

Frayssinet, N. and Cáceres, G. 2002. Habranthus brachyandrus y H. martinezii: híbridos interespecíficos. 1er Congreso Argentino de Floricultura y Plantas Ornamentales y 4ta Jornadas Nacionales de Floricultura: 15

Gabrielsen, B., Monath, T.P., Huggins, J.W., Kefauver, D.F, Pettit, G.R., Groszek, G., Hollingshead, G., Kirsi, J.J., Shannon, W.M., Schubert, E.M., Dare, J., Ugarkar, B., Ussery, M.A. and Phelan, M.J. 1992. Antiviral (RNA) activity of selected Amaryllidaceae isoquinoline constituents and synthesis of related substances. J. Nat. Prod. 55:1569-1581.

Hurrell, J.A., Bazzano, D.H. and Delucchi, G. 2005. Biota Rioplatense X. Monocotiledóneas Herbáceas, Nativas y Exóticas. Ed. L.O.L.A. Buenos Aires, Argentina. 319 pp.

Martin, F. 1958. Staining and observing pollen tubes in the styles by means of fluorescence. Stain Tech. 34:125-128.

Pettit, G.R., Groszek, G., Backhaus, R.A., Doubek, D.L., Barr, R.J. and Meerow, A.W. 1995. Antineoplastic agents. An investigation of the Amaryllidaceae genus Hymenocallis. J. Nat. Prod. 58:756-759.

Ruiz, T. Z. and Arroyo, M.T.K. 1978. Plant reproductive ecology of secondary deciduous forest in Venezuela. Biotropica 19:221-230.

Saavedra, F., Arroyo, M.T.K. and Hoffmann, A.J. 1996. The breeding system of Hyppeastrum advenum (Ker-Gawl.) Herb. (Amaryllidaceae), an endemic bulbous geophyte of the mediterranean-type climate region in central Chile. Bot. Jahrb. Syst. 118:1-8.

Sage, T.L., Strumas, F., Cole, W.W. and Barrett, S.C.H. 1999. Differential ovule development following self- and cross-pollination: the basis of self-sterility in Narcissus triandrus (Amaryllidaceae). Amer. J. Bot. 86:855-870.

Schmeda-Hirschmann, G., Rodríguez, J.A., Loyola, J.I., Astudillo, L., Bastida, J., Viladomat, F. and Codina, C. 2000. Activity of Amaryllidaceae alkaloids on the blood pressure of normotensive rats. Phar. and Pharm. Com. 6:309-312.

Sills, C., Frayssinet, N. and Basso, A. 2002. Bandeo C en Habranthus brachyandrus y $H$. martinezii. 1er Congreso Argentino de Floricultura y Plantas Ornamentales y 4ta Jornadas Nacionales de Floricultura: 51

Viladomat, F., Bastida, J., Codina, C., Nair, J.J. and Campbell, W.E. 1997. Alkaloids of the South African Amaryllidaceae, In: S.G. Pandalai, Ed., Recent Research Developments in Phytochemistry, vol. 1 Research Signpost. Trivandrum. pp. 131-171.

Webb, C.J. and Lloyd, D. G. 1986. The avoidance of interference between the presentation of pollen and stigmas in Angiosperms. 2. Hercogamy. New Zealand J. Bot. 24:163-178.

Weniger, B., Italiano, L., Beck, J.P., Bastida, J., Bergoñón, S., Codina, C., Lobstein, A. and Anton, R. 1995. Cytotoxic activity of Amaryllidaceae alkaloids. Planta Medica 61:7779.

Wiens, D., Calvin, C. L., Wilson, C. A., Davern, C. I., Frank, C., Seavey, S. R. 1987. Reproductive success, spontaneous embryo abortion, and genetic load in flowering plants. Oecologia 71: 501-509.

Zapata, T. R. and Arroyo, M. T. K. 1978. Plant reproductive ecology of a secondary deciduous tropical forest in Venezuela. Biotropica 10: 221-230. 
Zuloaga, F.O., Morrone, O., Belgrano, M.J. 2008. Catálogo de las Plantas Vasculares del Cono Sur (Argentina, Sur de Brasil, Chile, Paraguay y Uruguay). Monogr. Syst. Bot. Missouri Bot. Gard. 107(1): 1-983.

\section{$\underline{\text { Tables }}$}

Table 1: Fruit setting, average number of seeds per fruit and reproductive efficiency (\% $\mathrm{RE}$ ) in self and cross pollinated plants and not pollinated plants of Habranthus tubispathus.

\begin{tabular}{cccc}
\hline & $\begin{array}{c}\text { Self- } \\
\text { pollination }\end{array}$ & $\begin{array}{c}\text { Cross- } \\
\text { pollination }\end{array}$ & $\begin{array}{c}\text { Without } \\
\text { pollination }\end{array}$ \\
\hline $\begin{array}{c}\text { No of pollinated flowers } \\
\text { No of set fruits (\%) } \\
\text { Average number of } \\
\quad \begin{array}{c}\text { seeds/fruit } \\
\text { Reproductive efficiency } \\
(\% \text { RE) }\end{array}\end{array}$ & $57(59.4)$ & $64(91.4)$ & $0(0)$ \\
\hline
\end{tabular}




\section{Figure:}

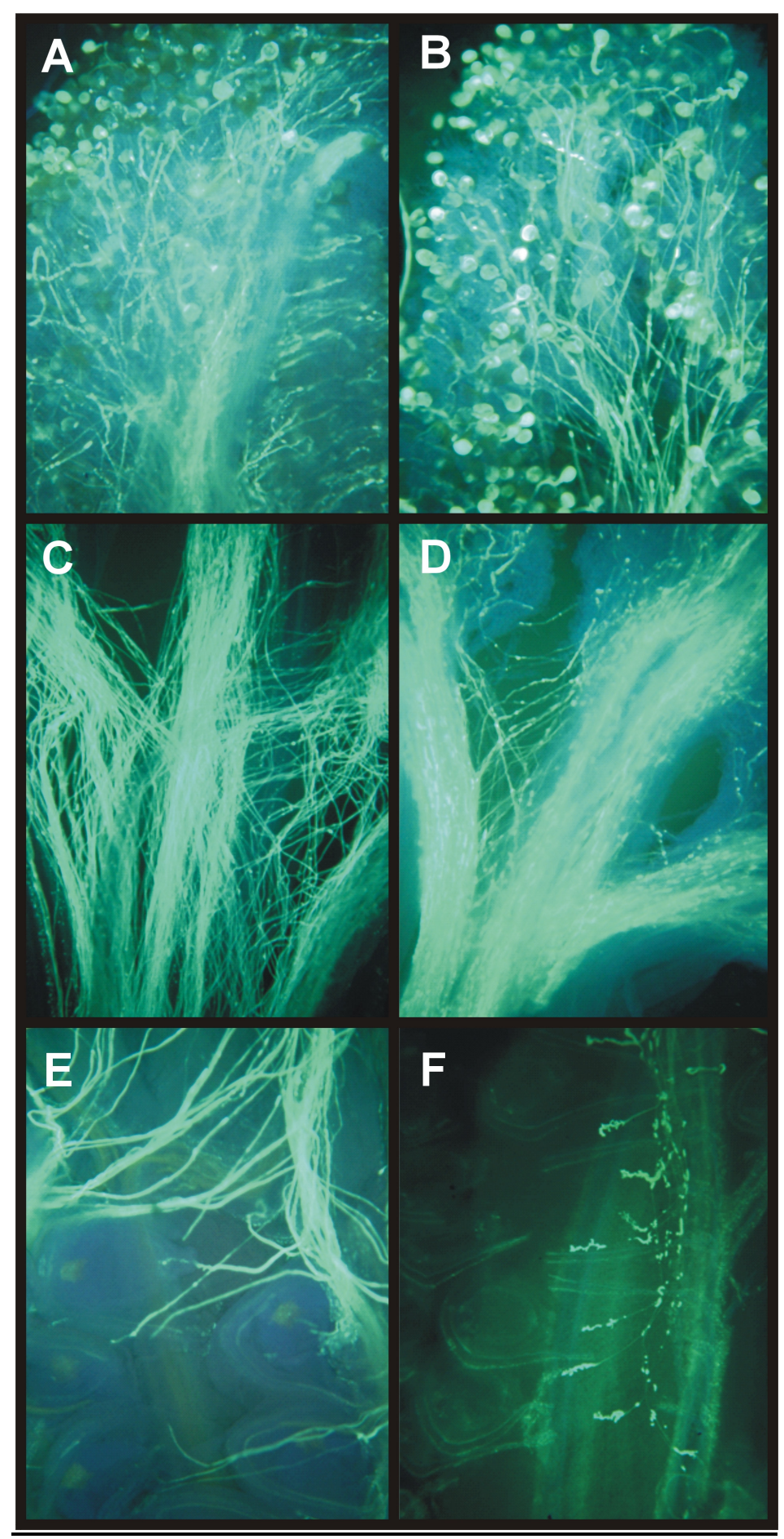

Figure 1: Pollen tube growth in the stigma $(\mathrm{A}, \mathrm{B})$, the style $(\mathrm{C}, \mathrm{D})$ and the ovules $(\mathrm{E}, \mathrm{F})$ of Habranthus tubispathus. Self- (A, C, E) and cross- (B, D, F) pollinated flowers. 